\title{
APLIKASI PREDIKSI USIA KELAHIRAN DENGAN METODE NAIVE BAYES
}

\author{
Naisha Rahma Indraswari \\ Fakultas Komunikasi dan Informatika, Program Studi Informatika \\ Universitas Muhammadiyah Surakarta \\ Email: naisharahmai@gmail.com \\ Yogiek Indra Kurniawan \\ Fakultas Komunikasi dan Informatika, Program Studi Informatika \\ Universitas Muhammadiyah Surakarta \\ Email:yogiek@ums.ac.id
}

\begin{abstract}
ABSTRAK
Umumnya kelahiran bayi sehat cukup bulan berada pada minggu 38-42 kehamilan. Namun ada banyak bayi yang terlahir pada usia kelahiran yang kurang mencukupi bahkan lahir dalam usia kelahiran yang lewat waktu. Hal ini menjadi hal yang serius mengingat banyak terjadi kematian bayi akibat usia kelahiran yang kurang mencukupi atau yang lewat waktu. Penelitian ini bertujuan untuk membuat aplikasi prediksi yang nantinya akan dapat membantu pasien dalam mengetahui usia kelahirannya dan mengantisipasi hal yang tidak diinginkan kedepannya. Metode yang digunakan merupakan metode Naïve Bayes dengan variable inputan faktor-faktor yang dialami oleh ibu hamil, diantaranya: usia ibu, tekanan darah, jumlah bayi, riwayat persalinan, riwayat abortus/ kuretase, malnutrisi, penyakit bawaan sebelum hamil dan masalah saat kehamilan. Hasil dari penelitian ini merupakan sebuah aplikasi yang dapat memprediksi usia kelahiran dengan nilai akurasi aplikasi tertinggi pada angka $78,69 \%$, nilai precision tertinggi ada pada angka $70.14 \%$ dan nilai recall tertinggi ada pada angka $63.64 \%$.
\end{abstract}

Kata kunci: aplikasi, naïve bayes, prediksi, usia kelahiran.

\begin{abstract}
Generally babies born at 38-42 weeks of pregnancy. But, there are a lot of babies born at preterm pregnancy and even there are babies born at posrterm pregnancy. This problem becomes a serious thing considering that many babies deaths due to preterm pregnancy or postterm pregnancy. The goals of this study is to create a prediction application that will be able to help patients to knowing the age of birth and anticipate the unexpected thing going forward. The method used is Naïve Bayes method with variable input factors by pregnant mother. They are, age, blood pressure, number of infants, birth history, abortion / curettage history, malnutrition, congenital disease and pregnancy problems. The results of this study is an application that can predict the age of birth with highgest accuracy value of this application on number $78.69 \%$, highgest precision value on number $70.14 \%$ and highgest recall value on number $63.64 \%$.
\end{abstract}

Keywords: application, birth, nä̈ve bayes, prediction.

\section{PENDAHULUAN}

Angka kelahiran bayi di Indonesia setiap tahunnya cenderung semakin bertambah. Angka kelahiran bayi ini diiringi angka kematian bayi baru lahir yang besar pula. Banyak hal yang menyebabkan bayi yang baru lahir meninggal, beberapa diantaranya adalah kekurangan nutrisi pada saat dalam kandungan, janin yang memiliki cacat dalam tubuhnya, faktor kelahiran usia premature, faktor usia kelahiran postmature/postdate dan lain lain. Kematian akibat kelahiran premature tentunya menjadi masalah yang cukup serius. Menurut hasil riset yang dilakukan WHO pada tahun 2010, Indonesia merupakan negara yang menempati peringkat ke 5 tertinggi dengan 675.700 kelahiran premature dalam satu tahun. Angka ini masih cukup rendah dibandingkan negara India yang mencapai 3,5 Juta kelahiran premature per tahunnya. Hal ini menyebabkan India menempati urutan pertama jumlah kelahiran premature tertinggi diantara 184 negara lain. Di urutan ke-2 adalah China dengan jumlah 1,1 juta kelahiran premature diikuti Nigeria dan Pakistan. Indonesia masuk dalam urutan ke 9 jumlah rata-rata kelahiran premature tertinggi dengan angka kelahiran 15.5 per 100 kelahiran [1].

Lebih dari 15 Juta kelahiran premature terjadi di dunia dan terus meningkat setiap tahunnya. Lebih dari 1 juta anak meninggal setiap tahunnya karena komplikasi akibat kelahiran premature. Kelahiran 
premature merupakan penyebab kematian bayi baru lahir dengan umur kurang dari 4 minggu dan merupakan penyebab kematian kedua pada anak dibawah umur 5 tahun selain pneumonia. Sementara itu, bayi yang berhasil hidup mengalami kecacatan yang mereka alami seumur hidup diantaranya gangguan pada saat belajar dan visual serta masalah pendengaran [2]. Anak yang terlahir premature memiliki resiko yang lebih tinggi terhadap retardasi mental. Retardasi Mental (RM) atau biasa disebut dengan keterbelakangan mental atau disabilitas intelektual (DI) adalah suatu kelainan mental dimana tingkat kecerdasan berasa dibawah rata-rata orang normal lainnya (umumnya IQ kurang dari 70) dan gangguan dalam keteranpilan adaptif yang terjadi sebelum anak berusia 18 tahun [3].

Kelahiran postmature/postdate juga menimbulkan masalah yang cukup serius, diantaranya air ketuban yang semakin sedikit, fetal distress atau gawat janin, makrosomia atau bayi dengan berat badan lebih, fetal death atau janin meninggal dalam kandungan, bayi kekurangan nutrisi dan oksigen, dan lain lain. Kelahiran postmature/postdate menyebabkan bayi yang lahir memiliki tingkat pertumbuhan yang lambat. Kelahiran postmature/postdate biasanya terjadi pada kelahiran anak pertama.

Berdasarkan permasahan yang telah disebutkan diatas, perlu untuk kita mengetahui faktor-faktor apa saja yang mempengaruhi usia kelahiran pada bayi agar tidak terjadi hal yang tidak diinginkan kedepannya. Penelitian ini bertujuan untuk memprediksi usia kelahiran menjadi 3 kategori berdasarkan faktor-faktor yang dialami oleh ibu hamil dengan menggunakan aplikasi prediksi. Kategori usia kelahiran yang ada di penelitian ini diantaranya adalah premature, normal atau cukup bulan, dan postmature atau postdate.

Nugroho \& Subanar (2013) menggunakan Metode Naïve Bayes untuk memprediksi kelahiran pada ibu hamil untuk mengurangi Angka Kematian Ibu (AKI) dan Angka Kematian Bayi (AKB). Variabel yang digunakan adalah karakteristik yang dialami ibu hamil antara lain, usia ibu, tinggi badan, jumlah $\mathrm{Hb}$, tekanan darah, riwayat kehamilan dan penyakit bawaan. Hasil akhir dari penelitian ini adalah sistem klasifikasi menggunakan bahasa $\mathrm{R}$ dengan output prediksi ibu hamil mengalami kelahiran beresiko dan kelahiran normal [4].

Nugroho \& Hayarti (2015) menggunakan perbandingan 3 metode dalam penelitiannya. Metode yang digunakan adalah Algoritma C.45, Algoritma K-Means dan Naïve Bayes untuk melakukan klasifikasi dan klastering terhadap penjurusan siswa di SMAN 3 Boyolali. Penelitian ini bertujuan untuk menentukan penjurusan yang tepat bagi siswa agar siswa dapat memaksimalkan potensi, bakat dan nilai akademisnya [5]. Marlina, et. al. (2017) menggunakan Naïve Bayes Classifier dalam sistem pakar yang dibagun. Penelitian ini bertujuan untuk memudahkan mendiagnosa penyakit ISPA dengan menggunakan konversi hasil suara pasien [6].

Berdasarkan telaah pustaka diatas, penelitian ini akan membuat aplikasi prediksi usia kelahiran yang akan dibangun menggunakan metode Naïve Bayes. Alasan penulis memilih untuk menggunakan metode Naïve Bayes adalah Naïve Bayes merupakan metode klasifikasi dengan rumus yang sederhana dan mudah untuk di aplikasikan serta metode Naïve Bayes memiliki tingkat akurasi yang cukup tinggi dibandingkan dengan metode lainnya. Dengan adanya aplikasi prediksi usia kelahiran ini diharapkan akan dapat membantu mengurangi resiko kematian bayi akibat usia kelahiran yang terlalu muda maupun terlalu tua dan mengantisipasinya sejak dini.

\section{METODOLOGI}

Pada bagian metodologi ini akan dijelaskan tahap-tahap yang dilakukan dalam penelitian dari awal hingga akhir. Tahap-tahap dalam peneltian ini ditunjukkan dalam gambar 1 .

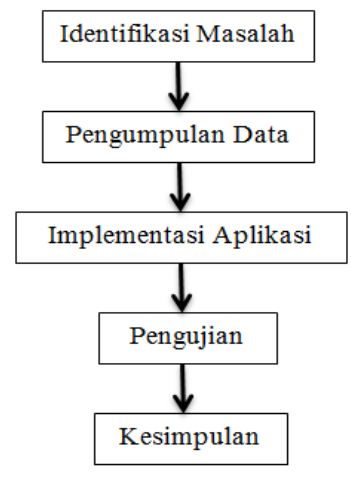

Gambar 1. Metodologi Penelitian 


\subsection{Identifikasi Masalah}

Pada tahap identifikasi masalah merupakan tahap awal yang bertujuan untuk menentukan masalahmasalah apa saja yang ada dalam kelahiran bayi. Berdasarkan masalah yang ada di lapangan maka dibutuhkan sebuah aplikasi untuk memprediksi usia kelahiran menjadi 3 kategori usia.

\subsection{Pengumpulan Data}

Data yang diperoleh dalam penelitian ini adalah data yang didapatkan dari data rekam medik pasien melahirkan di RSUD. Dr. Moewardi Provinsi Jawa Tengah dan Klinik Pratama An-Nisa selama tahun 2016. Serta untuk data testing menggunakan data rekam medik pasien melahirkan selama bulan Januari 2017 hingga bulan September 2017. Penjelasan data yang diambil dalam rekam medik pasien ada dalam tabel 1 .

Tabel 1. Penjelasan variable yang diperlukan

\begin{tabular}{|c|c|c|c|}
\hline Variable & Atribut & Tipe & Keterangan \\
\hline $\mathrm{X} 1$ & Usia Ibu & Polinomial & $\begin{array}{ll}\text { a. } & \text { Kurang }(<20 \text { tahun }) \\
\text { b. } & \text { Cukup }(20-35 \text { tahun }) \\
\text { c. } & \text { Lebih }(>35 \text { tahun }) \\
\text { a. } & \text { Rendah }(<90 / 70 \mathrm{mmHg})\end{array}$ \\
\hline $\mathrm{X} 2$ & Tekanan Darah & Polinomial & $\begin{array}{l}\left.\text { b. Normal ( } 90 / 70^{-140 / 90} \mathrm{mmHg}\right) \\
\text { c. Tinggi ( }>140 / 90 \mathrm{mmHg})\end{array}$ \\
\hline $\mathrm{X} 3$ & Jumlah Bayi & Binomial & $\begin{array}{l}\{1,2\} \\
\text { a. } \quad \text { Riwayat premature }\end{array}$ \\
\hline $\mathrm{X} 4$ & $\begin{array}{l}\text { Riwayat } \\
\text { Persalinan }\end{array}$ & Polinomial & $\begin{array}{l}\text { b. Riwayat postmature/postdate } \\
\text { c. Riwayat melahirkan usia normal } \\
\text { d. Jarak yang singkat dengan } \\
\text { kehamilan sebelumnya ( }<2 \text { tahun ) } \\
\text { e. Persalinan Pertama }\end{array}$ \\
\hline $\begin{array}{l}X 5 \\
X 6\end{array}$ & $\begin{array}{l}\text { Riwayat Abortus } \\
\text { Malnutrisi }\end{array}$ & $\begin{array}{l}\text { Binomial } \\
\text { Polinomial }\end{array}$ & $\begin{array}{l}\{\text { Ya, Tidak }\} \\
\{\text { Kurang, Normal, Lebih }\}\end{array}$ \\
\hline $\mathrm{X7}$ & Penyakit Lain & Polinomial & $\begin{array}{l}\text { a. Jantung } \\
\text { b. Asma } \\
\text { c. Hipertensi } \\
\text { d. Anemia } \\
\text { e. Diabetes Melitus } \\
\text { f. Tidak Ada }\end{array}$ \\
\hline $\mathrm{X} 8$ & $\begin{array}{l}\text { Masalah Saat } \\
\text { Kehamilan Ini }\end{array}$ & Polinomial & $\begin{array}{l}\text { a. Pre-eklamsia Ringan } \\
\text { b. Pre-eklamsia Berat } \\
\text { c. Hipertensi Gestasional } \\
\text { d. Perdarahan } \\
\text { e. Tidak Ada }\end{array}$ \\
\hline $\mathrm{Y}$ & Usia Kelahiran & Label & $\begin{array}{ll}\text { a. } & \text { Prematur }(<37 \text { minggu }) \\
\text { b. } & \text { Normal }(38-42 \text { minggu }) \\
\text { c. } & \text { Postdate }(>42 \text { minggu }) \\
\end{array}$ \\
\hline
\end{tabular}

Dalam pembangunan aplikasi diperlukan use case yang digunakan untuk menggambarkan penggunaan dan pengelolaan data dalam aplikasi sesuai dengan kebutuhan. Pada gambar 2 merupakan diagram use case yang akan digunakan dalam penelitian ini. 


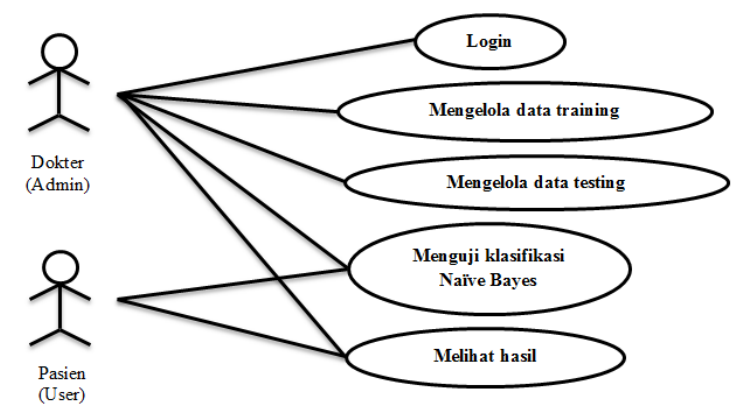

Gambar 2. Use Case Diagram

Keterangan:

a. $\log$ In

b. Mengelola data training

c. Mengelola data testing

d. Menguji klasifikasi

Naïve Bayes

e. Melihat hasil prediksi
: Dalam proses log in admin dapat memasukkan username dan password yang dimiliki setiap admin.

: Dalam tahap ini admin dapat menambah, mengubah dan menghapus data training yang ada dalam aplikasi. Data yang dimasukkan dapat berupa file dengan ekstensi excel atau data yang dimasukkan melaui form yang ada dalam aplikasi.

: Dalam tahap ini admin dapat menambah, mengubah dan menghapus data testing yang ada dalam aplikasi. Data yang dimasukkan dapat berupa file dengan ekstensi excel atau data yang dimasukkan melaui form yang disediakan dalam aplikasi.

: Dalam tahap ini admin dan user dapat menguji hasil klasifikasi dengan memasukkan data melalui form yang ada dalam aplikasi.

: Dalam tahap ini admin dan user dapat melihat hasil pengujian yang mereka masukkan sebelumnya.

\subsection{Implementasi Aplikasi}

Pada tahap implementasi aplikasi ini bertujuan untuk membangun aplikasi dari awal sesuai dengan kebutuhan. Aplikasi yang akan dibangun merupakan aplikasi berbasis web dengan bahasa pemrograman PHP dan database MySQL. Dalam aplikasi akan di implementasikan algoritma klasifikasi Naïve Bayes.

Bayes merupakan teknik prediksi berbasis probabilistik sederhana yang berdasar pada penerapan teorema Bayes atau aturan Bayes dengan asumsi independensi (ketidaktergantungan) yang kuat (naï) [7]. Metode Bayes merupakan pendekatan statistic untuk melakukan inferensi induksi pada persoalan klasifikasi [8].

Keuntungan menggunakan klasifikasi Nä̈ve Bayes adalah metode ini hanya memerlukan data training yang sedikit untuk membuat (mean dan varians dari variabel) yang diperlukan untuk klasifikasi. Karena variabel independen diasumsikan, hanya varians variabel masing-masing kelas yang harus ditentukan dan bukan keseluruhan matriks kovarians [9].

Prediksi Bayes didasarkan pada teorema Bayes dengan formula umum yang terdapat di persamaan 1 berikut: [7].

$\mathrm{P}(\mathrm{H} \mid \mathrm{E})=\frac{\mathrm{P}(\mathrm{E} \mid \mathrm{H}) \times \mathrm{P}(\mathrm{H})}{\mathrm{P}(\mathrm{E})}$

Keterangan:

$\mathrm{P}(\mathrm{H} \mid \mathrm{E})$ : Probabilitas akhir bersyarat (conditional probability) suatu hipotesis $\mathrm{H}$ terjadi jika diberikan bukti (evidence) E terjadi.

$\mathrm{P}(\mathrm{E} \mid \mathrm{H})$ : Probabilitas sebuah bukti E akan memengaruhi hipotesis $\mathrm{H}$.

$\mathrm{P}(\mathrm{H})$ : $\quad$ Probabilitas awal hipotesis $\mathrm{H}$ terjadi tanpa memandang bukti apapun.

$\mathrm{P}(\mathrm{E})$ : Probabilitas awal bukti E terjadi tanpa memandang hipotesis/bukti yang lain. 
Berikut adalah contoh penerapan Naïve Bayes pada data yang penulis dapatkan. Data yang didapat dalam penelitian ini dibagi menjadi dua bagian, yaitu data training dan data testing. Pada tabel 2 merupakan data training yang digunakan untuk memperoleh model serta pada tabel 3 merupakan data testing untuk menguji model dari perhitungan data training.

Tabel 2. Data Training

\begin{tabular}{|c|c|c|c|c|c|c|c|c|}
\hline Usia & $\begin{array}{c}\text { Tekanan } \\
\text { Darah }\end{array}$ & $\begin{array}{c}\text { Jml } \\
\text { Bayi }\end{array}$ & $\begin{array}{c}\text { Riwayat } \\
\text { Persalinan }\end{array}$ & $\begin{array}{l}\text { Riwayat } \\
\text { Abortus }\end{array}$ & Nutrisi & $\begin{array}{l}\text { Penyakit } \\
\text { Lain }\end{array}$ & $\begin{array}{c}\text { Masalah } \\
\text { Saat } \\
\text { Hamil } \\
\end{array}$ & $\begin{array}{c}\text { Usia } \\
\text { Kelahiran }\end{array}$ \\
\hline Lebih & Tinggi & 1 & $\begin{array}{l}\text { Riwayat } \\
\text { Normal }\end{array}$ & Tidak & Normal & $\begin{array}{c}\text { Tidak } \\
\text { Ada }\end{array}$ & PEB & Postdate \\
\hline Kurang & Normal & 1 & $\begin{array}{l}\text { Riwayat } \\
\text { Normal }\end{array}$ & Tidak & Normal & $\begin{array}{c}\text { Tidak } \\
\text { Ada }\end{array}$ & $\begin{array}{l}\text { Tidak } \\
\text { Ada }\end{array}$ & Normal \\
\hline Lebih & Normal & 1 & $\begin{array}{l}\text { Riwayat } \\
\text { Prematur }\end{array}$ & $\mathrm{Ya}$ & Normal & Anemia & $\begin{array}{c}\text { Tidak } \\
\text { Ada }\end{array}$ & Premature \\
\hline Cukup & Tinggi & 1 & $\begin{array}{c}\text { Anak } \\
\text { Pertama }\end{array}$ & Tidak & Normal & Anemia & PER & Postdate \\
\hline Cukup & Normal & 1 & $\begin{array}{l}\text { Riwayat } \\
\text { Prematur }\end{array}$ & Tidak & Normal & $\begin{array}{c}\text { Tidak } \\
\text { Ada }\end{array}$ & $\begin{array}{l}\text { Tidak } \\
\text { Ada }\end{array}$ & Normal \\
\hline Cukup & Tinggi & 1 & $\begin{array}{c}\text { Anak } \\
\text { Pertama }\end{array}$ & Tidak & Normal & Hipertensi & PEB & Premature \\
\hline
\end{tabular}

Lanjutan Tabel 2. Data Training

\begin{tabular}{ccccccccc}
\hline Usia & $\begin{array}{c}\text { Tekanan } \\
\text { Darah }\end{array}$ & $\begin{array}{c}\text { Jml } \\
\text { Bayi }\end{array}$ & $\begin{array}{c}\text { Riwayat } \\
\text { Persalinan }\end{array}$ & $\begin{array}{c}\text { Riwayat } \\
\text { Abortus }\end{array}$ & Nutrisi & $\begin{array}{c}\text { Penyakit } \\
\text { Lain }\end{array}$ & $\begin{array}{c}\text { Masalah } \\
\text { Saat } \\
\text { Hamil }\end{array}$ & $\begin{array}{c}\text { Usia } \\
\text { Kelahiran }\end{array}$ \\
\hline Lebih & Normal & 1 & $\begin{array}{c}\text { Riwayat } \\
\text { Normal }\end{array}$ & Tidak & Normal & $\begin{array}{c}\text { Tidak } \\
\text { Ada }\end{array}$ & $\begin{array}{c}\text { Tidak } \\
\text { Ada }\end{array}$ & Normal \\
Lebih & Tinggi & 1 & $\begin{array}{c}\text { Riwayat } \\
\text { Prematur } \\
\text { Anak }\end{array}$ & Ya & Normal & Asma & PER & Premature \\
Lebih & Normal & 1 & $\begin{array}{c}\text { Pertama } \\
\text { Riwayat } \\
\text { Normal }\end{array}$ & Tidak & Kurang & Asma & $\begin{array}{c}\text { Tidak } \\
\text { Ada }\end{array}$ & Premature \\
Tidak & Normal & $\begin{array}{c}\text { Tidak } \\
\text { Ada }\end{array}$ & $\begin{array}{c}\text { Tidak } \\
\text { Ada }\end{array}$ & Premature \\
\hline
\end{tabular}

Tabel 3. Data Testing

\begin{tabular}{ccccccccc}
\hline Usia & $\begin{array}{c}\text { Tekanan } \\
\text { Darah }\end{array}$ & $\begin{array}{c}\text { Jml } \\
\text { Bayi }\end{array}$ & $\begin{array}{c}\text { Riwayat } \\
\text { Persalinan }\end{array}$ & $\begin{array}{c}\text { Riwayat } \\
\text { Abortus }\end{array}$ & Nutrisi & $\begin{array}{c}\text { Penyakit } \\
\text { Lain }\end{array}$ & $\begin{array}{c}\text { Masalah } \\
\text { Saat } \\
\text { Hamil }\end{array}$ & $\begin{array}{c}\text { Usia } \\
\text { Kelahiran }\end{array}$ \\
\hline Cukup & Tinggi & 1 & $\begin{array}{c}\text { Anak } \\
\text { Pertama }\end{array}$ & Tidak & Normal & Hipertensi & PEB & $?$ \\
\hline
\end{tabular}

Hasil perhitungan dari tabel 2 dapat digunakan untuk menentukan kelas usia kelahiran tabel 3 yang dijabarkan seperti dibawah ini:

a. Menghitung jumlah probabilitas variabel $\mathrm{Y}$

$$
\begin{array}{ll}
P(Y=\text { Premature })=\frac{5}{10}=0,5 & P(Y=\text { Normal })=\frac{3}{10}=0,3 \\
P(Y=\text { Postdate })=\frac{2}{10}=0,2 &
\end{array}
$$

b. Menghitung probabilitas variable $\mathrm{X}$ terhadap variable $\mathrm{Y}$

$$
\begin{array}{lr}
P\left(X_{1}=\text { Cukup } \mid Y=\text { Premature }\right)=\frac{2}{5} & P\left(X_{5}=\text { Tidak } \mid Y=\text { Premature }\right)=\frac{3}{5} \\
P\left(X_{1}=\text { Cukup } \mid Y=\text { Normal }\right)=\frac{1}{3} & P\left(X_{5}=\text { Tidak } \mid Y=\text { Normal }\right)=\frac{3}{3} \\
P\left(X_{1}=\text { Cukup } \mid Y=\text { Postdate }\right)=\frac{1}{2} & P\left(X_{5}=\text { Tidak } \mid Y=\text { Postdate }\right)=\frac{2}{2} \\
P\left(X_{2}=\text { Tinggi } \mid Y=\text { Premature }\right)=\frac{2}{5} & P\left(X_{6}=\text { Normal } \mid Y=\text { Premature }\right)=\frac{4}{5} \\
P\left(X_{2}=\text { Tinggi } \mid Y=\text { Normal }\right)=\frac{0}{3} & P\left(X_{6}=\text { Normal } \mid Y=\text { Normal }\right)=\frac{3}{3} \\
P\left(X_{2}=\text { Tinggi } \mid Y=\text { Postdate }\right)=\frac{2}{2} & P\left(X_{6}=\text { Normal } \mid Y=\text { Postdate }\right)=\frac{2}{2}
\end{array}
$$




$$
\begin{array}{lc}
P\left(X_{3}=1 \mid Y=\text { Premature }\right)=\frac{4}{5} & P\left(X_{7}=\text { Hipertensi } \mid Y=\text { Premature }\right)=\frac{1}{5} \\
P\left(X_{3}=1 \mid Y=\text { Normal }\right)=\frac{3}{3} & P\left(X_{7}=\text { Hipertensi } \mid Y=\text { Normal }\right)=\frac{0}{3} \\
P\left(X_{3}=1 \mid Y=\text { Postdate }\right)=\frac{2}{2} & P\left(X_{7}=\text { Hipertensi } \mid Y=\text { Postdate }\right)=\frac{0}{2} \\
P\left(X_{4}=\text { Anak } 1 \mid Y=\text { Premature }\right)=\frac{2}{5} & P\left(X_{8}=P E B \mid Y=\text { Premature }\right)=\frac{1}{5} \\
P\left(X_{4}=\text { Anak } 1 \mid Y=\text { Normal }\right)=\frac{0}{3} & P\left(X_{8}=P E B \mid Y=\text { Normal }\right)=\frac{0}{3} \\
P\left(X_{4}=\text { Anak } 1 \mid Y=\text { Postdate }\right)=\frac{1}{2} & P\left(X_{8}=P E B \mid Y=\text { Postdate }\right)=\frac{1}{2}
\end{array}
$$

c. Membandingkan hasil probabilitas tiap kelas

$P\left(X_{1}=\right.$ Cukup,$X_{2}=$ Tinggi, $X_{3}=1, X_{4}=$ Anak $1, X_{5}=$ Tidak, $X_{6}=$ Normal, $X_{7}=$ Hipertensi, $X_{8}=P E B \mid Y=$ Premature)

$=\frac{2}{5} \times \frac{2}{5} \times \frac{4}{5} \times \frac{2}{5} \times \frac{3}{5} \times \frac{4}{5} \times \frac{1}{5} \times \frac{1}{5}=0,00073728$

$P\left(X_{1}=\right.$ Cukup,$X_{2}=$ Tinggi, $X_{3}=1, X_{4}=$ Anak $1, X_{5}=$ Tidak, $X_{6}=$ Normal, $X_{7}=$ Hipertensi, $X_{8}=P E B \mid Y=$ Normal)

$$
=\frac{1}{3} \times \frac{0}{3} \times \frac{3}{3} \times \frac{0}{3} \times \frac{3}{3} \times \frac{3}{3} \times \frac{0}{3} \times \frac{0}{3}=0
$$

$P\left(X_{1}=\right.$ Cukup,$X_{2}=$ Tinggi, $X_{3}=1, X_{4}=$ Anak $1, X_{5}=$ Tidak, $X_{6}=$ Normal, $X_{7}=$ Hipertensi, $X_{8}=P E B \mid Y=$ Postdate)

$$
=\frac{1}{2} \times \frac{2}{2} \times \frac{2}{2} \times \frac{1}{2} \times \frac{2}{2} \times \frac{2}{2} \times \frac{0}{2} \times \frac{1}{2}=0
$$

Dari perhitungan di atas telah diketahui bahwa probabilitas terbesar ada pada $P(Y=$ Premature $)$ maka dapat disimpulkan data yang ada pada data testing berada pada kelas Premature.

\subsection{Pengujian}

Pengujian dilakukan untuk menguji perhitungan dalam data training dengan menggunakan data testing. Pada tahap pengujian ini pula dilakukan perhitungan untuk menguji dan mengukur tingkat precision, recall dan accuracy dari algoritma Naïve Bayes[10].

Precision merupakan perhitungan terhadap perkiraan proporsi kasus positif yang benar dan dirumuskan dalam persamaan 2: [11]

Precision $=\frac{T P}{T P+F P}$

Recall merupakan perhitungan terhadap perkiraan proporsi kasus positif yang diidentifikasi benar dan dirumuskan dalam persamaan 3:

Recall $=\frac{T P}{T P+F N}$

Accuracy merupakan perhitungan terhadap proporsi dari jumlah total prediksi yang benar dan dirumuskan dalam persamaan 4 :

Accuracy $=\frac{T P+T N}{T P+F P+T N+F N}$

Keterangan:

TP : True Positive

TN : True Negative

FP : False Positive

FN : False Negative

\subsection{Kesimpulan}

Pada tahap ini akan dirumuskan kesimpulan berdasarkan penelitian yang telah dilakukan. Apakah sudah sesuai dengan tujuan dan harapan yang diinginkan atau belum. 


\section{HASIL DAN PEMBAHASAN}

\subsection{Implementasi}

Implementasi dari aplikasi yang telah dirancang sebelumnya menghasilkan sebuah aplikasi untuk memprediksi usia kelahiran. Dalam aplikasi ini terdapat 2 aktor yang dapat menggunakan aplikasi, yaitu dokter sebagai admin dan pasien sebagai user.

\subsection{Admin (Dokter)}

Admin mempunyai peran sebagai pengelola data dalam aplikasi. Admin di wajibkan untuk melakukan login terlebih dahulu dengan memasukkan username dan password yang dimiliki. Setelah melakukan login, maka admin akan langsung masuk ke halaman utama dengan beberapa menu yang dapat memudahkan admin mengelola data prediksi.

Menu dalam halaman utama admin diantaranya adalah: halaman utama, data latih (data training), data uji (data testing), accuracy, data total (data keseluruhan), data prediksi dan logout. Dalam menu data latih (data training) terdapat beberapa sub menu yang digunakan untuk mengelola data training, yaitu input data latih, input excel data latih dan lihat data latih.

Pada menu data uji (data testing) terdapat beberapa sub menu yang digunakan untuk mengelola data testing, yaitu input data uji, input excel data dan lihat data uji. Pada halaman lihat data uji terdapat button prediksi yang digunakan untuk menampilkan hasil prediksi data testing terdapat data training yang telah dikumpukan. Tampilan halaman hasil prediksi dari data testing dijelaskan pada gambar 4. Pada menu accuracy ditampilkan hasil accuracy, precision dan recall dari data training dan data testing aplikasi. Halaman accuracy dijelaskan pada gambar 3.

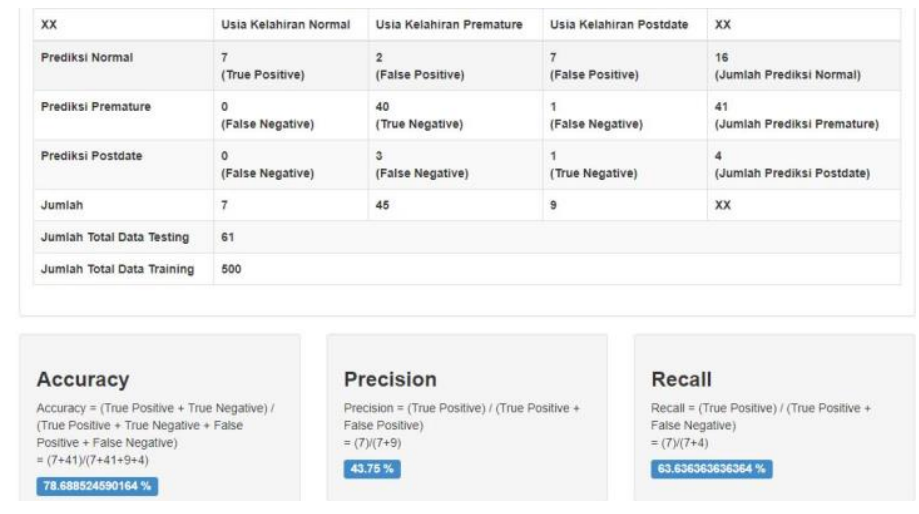

\section{Gambar 3. Halaman Accuracy}

Pada menu data total terdapat beberapa sub menu yang digunakan untuk mengelola data total, yaitu input data total, input excel data total dan lihat data total. Pada menu data prediksi terdapat beberapa sub menu yang digunakan untuk mengelola data prediksi, yaitu input data prediksi dan lihat data total.

Pada halaman input data prediksi jika telah selesai memasukkan data maka akan langsung di bawa ke halaman hasil prediksi yang dijelaskan ada gambar 4. Menu logout merupakan menu terakhir yang bertujuan untuk melakukan proses keluar dari halaman admin dan kembali ke halaman user. 


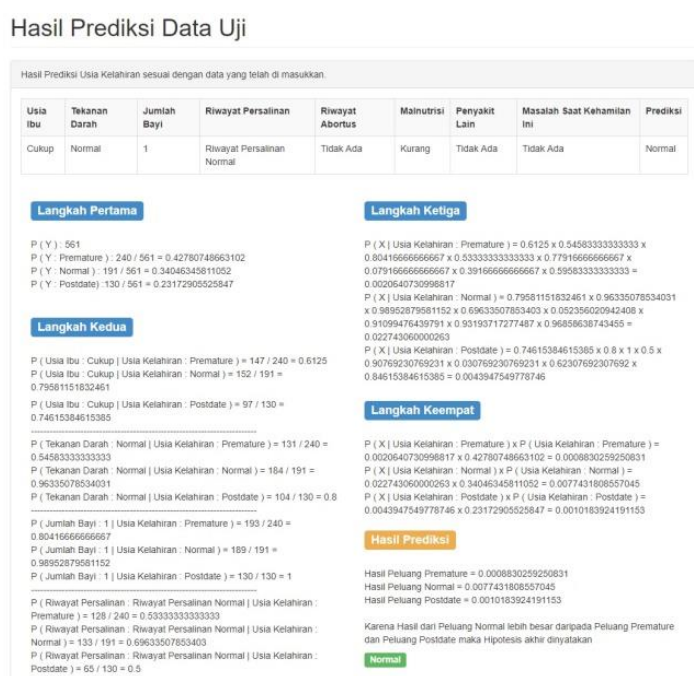

Gambar 4. Halaman Hasil Prediksi

\subsection{User (Pasien)}

User atau pasien hanya memiliki hak akses untuk melakukan prediksi usia kelahiran tanpa melakukan login. Menu dalam halaman utama user diantaranya adalah, halaman utama, halaman prediksi dan login. Penjelasan menu dalam halaman utama user. Pada menu prediksi, user akan diarahkan untuk memasukkan data yang akan diprediksi. Setelah data dimasukkan maka akan muncul tampilan hasil prediksi yang dijelaskan pada gambar 4. Menu login akan mengarahkan user untuk memasukkan username dan password yang hanya di miliki oleh admin.

\subsection{Pengujian}

Pada tahap pengujian dilakukan dengan 3 cara, yaitu dengan pengujian blackbox, pengujian algoritma Naïve Bayes dan pengujian tingkat accuracy, precision dan recall.

\subsubsection{Pengujian Blackbox}

Pengujian blackbox dilakukan untuk menguji modul-modul yang ada dalam aplikasi apakah berjalan sesuai dengan fungsinya. Pengujian blackbox dijelaskan dalam tabel 4.

Tabel 4. Pengujian Blackbox

\begin{tabular}{|c|c|c|c|}
\hline Modul & Scenario & Hasil yang diharapkan & $\begin{array}{l}\text { Hasil di } \\
\text { aplikasi }\end{array}$ \\
\hline Login. & Username dan password benar. & Masuk ke halaman admin & Valid \\
\hline Input data. & $\begin{array}{l}\text { Memasukkan data dan semua } \\
\text { data telah terisi. }\end{array}$ & $\begin{array}{l}\text { Data masuk kedalam database } \\
\text { dan masuk ke halaman lihat } \\
\text { data. }\end{array}$ & Valid \\
\hline $\begin{array}{l}\text { Input data } \\
\text { prediksi. }\end{array}$ & $\begin{array}{l}\text { Memasukkan data dan semua } \\
\text { data telah terisi. }\end{array}$ & $\begin{array}{l}\text { Data masuk kedalam database } \\
\text { dan masuk ke halaman hasil } \\
\text { prediksi. }\end{array}$ & Valid \\
\hline $\begin{array}{l}\text { Import data } \\
\text { excel. }\end{array}$ & $\begin{array}{l}\text { Memasukkan data dan semua } \\
\text { data telah terisi. }\end{array}$ & $\begin{array}{l}\text { Data masuk kedalam database } \\
\text { dan masuk ke halaman lihat } \\
\text { data. }\end{array}$ & Valid \\
\hline $\begin{array}{l}\text { Mengubah } \\
\text { data. }\end{array}$ & $\begin{array}{l}\text { Melakukan perubahan data dan } \\
\text { semua data telah terisi. }\end{array}$ & $\begin{array}{l}\text { Data berhasil diubah dalam } \\
\text { database dan masuk ke halaman } \\
\text { sebelumnya. }\end{array}$ & Valid \\
\hline $\begin{array}{l}\text { Menghapus } \\
\text { data. }\end{array}$ & $\begin{array}{l}\text { Melakukan penghapusan data } \\
\text { sesuai dengan yang diinginkan. }\end{array}$ & $\begin{array}{l}\text { Data terhapus dari database dan } \\
\text { masuk ke halaman sebelumnya. }\end{array}$ & Valid \\
\hline $\begin{array}{l}\text { Melakukan } \\
\text { prediksi pada } \\
\text { data. }\end{array}$ & $\begin{array}{l}\text { Melakukan pengisian data dan } \\
\text { semua data telah terisi. }\end{array}$ & $\begin{array}{l}\text { Data masuk kedalam database } \\
\text { dan masuk kehalaman prediksi. }\end{array}$ & Valid \\
\hline Logout. & Keluar dari aplikasi. & Keluar dari halaman admin. & Valid \\
\hline
\end{tabular}




\subsubsection{Pengujian Algoritma Nä̈ve Bayes}

Pengujian algoritma Naïve Bayes dilakukan dengan menggunakan 10 data training dan 6 data testing. Perhitungan untuk menguji kedua data tersebut dilakukan dengan cara perhitungan manual dan perhitungan dengan aplikasi yang telah diterapkan. Dari hasil yang didapat, perhitungan manual dibandingkan dengan perhitungan aplikasi memiliki hasil yang sama. Hal ini menunjukkan bahwa aplikasi yang dibangun berhasil menerapkan algoritma Naïve Bayes.

\subsubsection{Pengujian Precicion, Recall Dan Accuracy}

Pada tahap ini, penulis membagi data keseluruhan yang berjumlah 561 menjadi data training dan data testing secara berurutan. Hal ini bertujuan untuk menganalisa nilai precision, recall dan accuracy pada perhitungan algoritma Naïve Bayes pada aplikasi. Penjelasan pengujian precision, recall dan akurasi dapat dilihat dalam tabel 5.

Tabel 5. Pengujian Precision, Recall Dan Accuracy

\begin{tabular}{ccccc}
\hline Jumlah Data Training & Jumlah Data Testing & Precision & Recall & Accuracy \\
\hline 50 & 511 & $68.53 \%$ & $52.94 \%$ & $64.38 \%$ \\
100 & 461 & $66.50 \%$ & $60.27 \%$ & $65.94 \%$ \\
150 & 411 & $66.85 \%$ & $60.40 \%$ & $66.67 \%$ \\
200 & 361 & $70.14 \%$ & $59.76 \%$ & $69.25 \%$ \\
250 & 311 & $69.17 \%$ & $56.85 \%$ & $67.84 \%$ \\
300 & 261 & $66.34 \%$ & $60.36 \%$ & $70.11 \%$ \\
350 & 211 & $66.67 \%$ & $57.78 \%$ & $69.67 \%$ \\
400 & 161 & $60.38 \%$ & $48.49 \%$ & $65.84 \%$ \\
450 & 111 & $57.14 \%$ & $43.24 \%$ & $70.27 \%$ \\
500 & 61 & $43.75 \%$ & $63.64 \%$ & $78.69 \%$ \\
\hline
\end{tabular}

Tabel 5 diatas menunjukkan bahwa semakin bertambahnya data training maka tingkat accuracy akan cenderung semakin meningkat. Tingkat Accuracy yang semakin tinggi menunjukkan bahwa data yang ada dalam aplikasi memiliki tingkat kolektif data yang cukup tinggi untuk mengukur kedekatan antara nilai aktual dengan hasil prediksi.

Tingkat precision dan recall yang ada dalam aplikasi ini menunjukkan hasil yang cenderung menurun seiring bertambahnya data training. Tingkat recall yang semakin menurun seiring dengan bertambahnya data training menunjukkan bahwa data testing yang diprediksi benar dan relevan berjumlah lebih sedikit dari jumlah data testing yang bernilai benar. Hal ini menunjukkan bahwa tingkat keberhasilan sistem dalam memprediksi data sesuai dengan nilai aktual masih rendah.

Sedangkan tingkat precision yang semakin menurun seiring dengan bertambahnya data training menunjukkan bahwa data testing yang diprediksi benar dan relevan berjumlah lebih sedikit dari jumlah data testing yang diprediksi bernilai benar. Hal ini menunjukkan bahwa tingkat ketepatan sistem dalam memprediksi data sesuai dengan yang dihatapkan masih cukup rendah.

\subsection{Analisa Hasil}

Aplikasi prediksi usia kelahiran yang dibangun menggunakan metode Naïve Bayes ini memiliki 2 aktor dengan hak akses yang berbeda. Admin (dokter) dapat melakukan login dan logout serta dapat mengelola semua data yang ada dalam aplikasi. Sedangkan user (pasien) hanya dapat melakukan prediksi terhadap data yang telah dimasukkan sebelumnya. Data yang dimasukkan diantaranya, usia ibu, tekanan darah, jumlah bayi, riwayat abortus, riwayat persalinan sebelumnya, malnutrisi, penyakit bawaan sebelum hamil dan masalah saat kehamilan ini.

Pengujian aplikasi dilakukan dengan 3 cara, yaitu dengan pengujian blackbox, pengujian algoritma Naïve Bayes dan pengujian tingkat accuracy, precision dan recall. Pada pengujian blackbox menunjukkan bahwa semua modul yang ada dalam aplikasi dapat berjalan sesuai dengan yang diharapkan. Pada pengujian algoritma Naïve Bayes menunjukkan perhitungan manual dibandingkan dengan perhitungan aplikasi memiliki hasil yang sama. Sedangkan pengujian tingkat accuracy menunjukkan bahwa semakin banyak data training maka akan semakin tinggi tingkat accuracynya. 
Pengujian tingkat precision dan recall menunjukkan bahwa semakin banyak data training maka tingkat precision dan recall cenderung menurun.

\section{KESIMPULAN}

Hasil dari penelitian ini merupakan sebuah aplikasi prediksi usia kelahiran dengan menggunakan metode Naïve Bayes dengan hasil sebagai berikut:

a. Aplikasi memiliki 2 aktor yang memiliki hak akses yang berbeda. Dimana admin dan user dapat melakukan kegiatan prediksi dan hanya admin yang dapat melakukan login kedalam aplikasi.

b. Kegiatan prediksi dapat dilakukan setelah memasukkan data yang dialami ibu hamil yang kemudian akan menampilkan hasil prediksi sesuai dengan perhitungan Naïve Bayes.

c. Pengujian blackbox menunjukkan bahwa semua modul dalam aplikasi dapat berjalan dengan baik sesuai fungsinya.

d. Pengujian algoritma Naïve Bayes menunjukkan bahwa perhitungan manual dibandingkan dengan perhitungan aplikasi memiliki hasil yang sama.

e. Pengujian accuracy menunjukkan bahwa semakin banyak data maka tingkat akurasi semakin tinggi. Sedangkan pengujian tingkat precision dan recall, semakin banyak data training menunjukkan hasil yang cenderung menurun.

f. Nilai accuracy tertinggi pada aplikasi ini ada pada angka 78.69\%. Sedangkan nilai precision tertinggi ada pada angka $70.14 \%$ dan nilai recall tertinggi ada pada angka $63.64 \%$.

g. Untuk itu penulis menyarankan untuk mengembangkan aplikasi prediksi ini dengan metode yang lain dan memberikan lebih banyak data training agar tingkat accuracy, precision dan recall dapat meningkat.

\section{DAFTAR PUSTAKA}

[1] WHO. "Preterm Birth," World Health Organization., Updated November 2016, [Online]. Tersedia: http://www.who.int/mediacentre/factsheets/fs363/en/ [Diakses: 30 Oktober 2017].

[2] WHO. (2012). Born Too Soon: The Global Action Report on Preterm Birth. Tersedia: http://www.who.int/pmnch/media/news/2012/201204_borntoosoon-report.pdf [Diakses: 8 September 2017].

[3] Kurniawan, Y. I. dan Dwiyatmika, W. 2017. "Aplikasi Diagnosa Retardasi Mental Pada Anak". Prosiding SEMNAS Penguatan Individu di Era Revolusi Informasi, 336-343.

[4] Nugroho, A. dan Subanar. 2013. "Klasifikasi Naïve Bayes untuk Prediksi Kelahiran pada Data Ibu Hamil". Berkala MIPA 23. 3, 297-308.

[5] Nugroho, Y., dan Haryati, S. 2015. "Klasifikasi dan Klastering Penjurusan Siswa SMA Negeri 3 Boyolali”. Khazanah Informatika Jurnal Ilmu Komputer dan Informatika 1. 1, 1-6.

[6] Marlina, M., et. al. 2017. "Aplikasi sistem pakar diagnosis penyakit ISPA Berbasis Speech Recognition Menggunakan Metode Naive Bayes Classifier”. Jurnal Teknologi Informasi \& Komunikasi Digital Zone 8. 1, 58-70.

[7] Prasetyo, E. (2012). Data Mining: Konsep dan Aplikasi Mengginakan Matlab. Yogyakarta: Penerbit Andi.

[8] Liantoni, F., dan Nugroho, H. 2015. "Klasifikasi Daun Herbal Menggunakan Metode Naive Bayes Classifier dan K-Nearest Neighbor". Jurnal Ilmiah SismanteC 5. 1, 9-16.

[9] Vijayarani, S., dan Dhayanand, S. 2015. "Data Mining Classification Algorithms for Kidney Disease Prediction". International Journal on Cybernetics \& Informatics (IJCI) 4. 4, 13-25.

[10] Nugroho, Y. S., dan Gunawan, D. 2016. "Decision Tree Induction for Classifying the Cholesterol Levels". The $2^{\text {nd }}$ International Conference on Science, Technology and Humanity. 231-240.

[11] Vafeiadis, T., et. al. "A Compariosn Of Machine Learning Techniques For Customer Chrun Prediction". Simulation Modelling Practice and Theory. 55, 1-9. 